\title{
Albania's Trade Specialization and its Economic Growth Perspective in the Future.
}

\author{
Arjola Mitaj ${ }^{1}-\mathrm{PhD}(\mathrm{c})$, Klodian $\mathrm{Muco}^{1}-\mathrm{PhD}(\mathrm{c})$, Jonida Avdulaj ${ }^{1}$ - Phd (c)
}

\begin{abstract}
Starting from 1992, the Albanian economy has experienced a gradual openness. Initially, it was applied for the first time, the structural adjustment program which contained some basic aspects such as: a restrictive monetary policy for inflation control, liberalization of the economy and prices, public enterprises privatization in order to restructure and attract foreign investments, full market liberalization. It was also adopted the "open gate" policy that means a progressive opening of the country to foreign investment, which was based on comparative advantages of Albanian economic system, or more precisely on the low cost of labor force which is estimated at 90 cent for the fasson sector and call-center service, groundwater resources, its geographical position with access to both Adriatic and Ionian sea.

Based on the above facts, this paper will try to make an empirical analysis of comparative advantages of Albania, taking into account the degree of international trade openness and Balassa revealed comparative advantage (RCA). It will also be analyzed the structure of Albanian international trade and its production specialization in order to give some information on the future economic specialization of our country and help policy makers to orient economic development policies.
\end{abstract}

Keywords: foreign trade, economic development, commercial specialization.

\section{Introduction}

Countries trade between them because among all the other positive effects, trade puts a country in a better position than the initial one (a country without trade). In international trade, competition occurs at firm level, while the consumers of any country can benefit from free trade because they can provide a wider range of products and services, generally with a lower cost. If a country economically isolated from the rest of the world, decides to open its trade borders, its residents will specialize in those activities they better know how to do them. Thereby specialization leads to higher productivity, higher incomes and higher standards of living.

Comparative advantages enable countries to benefit from free trade, as long as resources are limited and all companies desire the maximum benefit from them. For a developing country like Albania, the benefits resulting from comparative advantages are more important. Thomas Sowell (2011) defines the importance of benefits from the comparative advantage in this way: "Comparative advantage means that there is a place under the free-trade sun for every nation, no matter how poor, because people of every 
country can produce some products relatively more efficiently than they produce other products."

In the early '80s, many governments of developing countries presented external oriented strategies as a way to increase production efficiency, as well as to promote the transmission of technology from developed countries. It was expected that an economy opened to international trade and capital flow, would improve growth and production and facilitate macroeconomic problems. If economic liberalization has achieved its purpose or not, up to now there is no widely accepted agreement. Globalization is conceived as a set of economic policies imposed by multinational organizations (International Monetary Fund, World Bank and World Trade Organization) to facilitate the movement of goods and capital.

As a process, globalization is neither new nor a completed process. According to Frankel $(2000)^{1}$, this process has its origins in the beginning of twentieth century, when the world became increasingly integrated with respect to trade and finance, when trade exchanges between countries increased significantly and the level of trade as a share of GDP was high. Rodrik $(1997)^{2}$ argues that is not whether or not the countries globalize their economies, but the way how they do this remains essential. According him the success or failure of liberalization reforms, depends on the existence of social conflicts and their proper management from the governments. Thus, to consolidate these changes, macroeconomic reforms should be accompanied by reforms in social and political institutions.

If Albania wants to benefit from globalization process and play a role in regional markets or even European ones, a role which is no sensitive so far, issues such as production or marketing systems, long-term competitiveness of exports, diversification of exports basket, not only would increase the market share of our country but also would create a broader base for higher export rates and trade deficit reduction over time. Such changes should occur in Albania, primarily as a domestic need of our country, and secondly because globalization is changing the context into which, are operating not only businesses, but all the interested parties, as an opportunity for countries to benefit from their competitive and comparative advantages. For this reason the issue of Albanian exports competitiveness increase, as part of the general strategy of growth and development, takes a great importance. The performance of Albanian exports improvement, consists not only in increasing the share that our country takes in regional or European markets, but also in diversifying the export basket to enable higher growth rates in the future. Precisely to achieve these necessary changes, Albania must find the proper way to achieve long-term competitiveness, which in turn emphasizes the need to adapt to international markets changes parallel to international standards. Furthermore stabilization policies and establishment of a belpful business environment for private development which ensure high growth rates shall be high on the agenda of policymakers? ${ }^{3}$.

Based on the mentioned issues, the following paragraphs will present an overview of our country's trade distribution, by product groups and geographic expansion, in order to identify the effect of trade liberalization on the competitiveness of Albanian products

\footnotetext{
${ }^{1}$ Frankel, J., (2000): “Globalization of the Economy”. National Bureau of Economic Research: Working Paper no. 7858. Pg.:21, 35.

2 Rodrik, D., (1997): “Globalization, Social Conflict and Economic Growth, Harvard University". Pg. 11

${ }^{3}$ Xhepa, S., Agolli, M.: “Albania’s Foreign Trade through a Gravity Approach”, Pg 15.
} 
and to give an answer to the question that what our country's well-diversified exports basket should contain. Because as it will be analyzed in the following issues, trade deficit has deepened year after year, with a growing negativity in almost all product categories (Table no. 2), except the category of textiles (fasson sector) which is not a final product destined for Albania, but a product that is re-exported after it is completed and ready for use.

\subsection{Problematic analysis and trade balance performance according products and markets. Identification of comparative advantages.}

Although the theory of comparative advantage is often attributed to David Ricardo, as a concept it was used for the first time by Robert Torrens in 1815 in his paper titled "An Essay on the foreign trade of corn"4. Ricardo $(1817)^{5}$, in his example of two countries Portugal and England, and two goods, wine and clothing, explained how free trade allows countries to benefit from increased specialization in those activities that own strong comparative advantage. Generally, comparative advantage is a concept used to explain patterns of specialization and trade. It refers to the possibility of an entity (country, region, company, or individual) to produce a product or service at a relatively low cost compared to other countries.

In economic terms, a country has a comparative advantage compared to another one in producing a good or service, if it can produce them at a lower opportunity cost, which assumes it has to give up from less labor or other production factor that could be used in the other products or services production.

\subsubsection{Economic development problems and trade exchanges}

With financial and economic crisis emerge of 2007, an overall deceleration of economic growth in many countries of Europe is noticed. Some of the economic models used on past decade do not function anymore (Zeneli, Czinkota, 2014). New incentives of development should have in focus employment and orientation towards exports and foreign investments. A country's economic growth will come as a result of investment orientation and improvement in order to increase productivity, reduce imports and raise exports (Garofoli, 2014). Regarding Albania, the so far export performance is disappointing. They are mainly concentrated in unprocessed raw materials and primarily in fasson products which exploit low cost of the labor force, and have a very low impact on the domestic economy and above all, do not produce for the domestic market ${ }^{6}$. Local companies face a number of challenges in terms of exports starting from the lack of qualified staff for market research, the difficulty to find new customers, the lack of package and conservation technology, and the preparation of a product at foreign markets standards. (Vangjeli, 2010).

Another problem is productivity, which is low and fragmented compared to the European one. Domestic product often is not enough to cover domestic consumption not even in priority sectors such as grocery, without forgetting the lack of value chain which would create synergy effects in reducing costs, increasing productivity, developing businesses beyond local borders and especially would create those that Hirschman called

\footnotetext{
${ }^{4}$ Torrens, Th.: (1815):" An Essay on the external corn trade"

${ }^{5}$ Ricardo, D.(1817): "Principles of political economy and taxation"

${ }^{6}$ ACIT Trade Report 2013, pg 31.
} 
upstream and downstream linkage (Hirschman, 1977) which from the other side would combine various economic sectors and generate an overall development.

Another problem is that of logistics and product storage and bargaining positions. Often domestic products because of the logistics and bargaining power of merchants for their products, especially in agriculture sector products fail to trade outside the products (Skreli and Tanku, 2002; De Meo, 2004). A typical case is that of cherries of Peshkopi which often fail to trade in Tirana market that is often supplied from outside because the price demanded from the wholesale traders is often equal to the price of their collection. This phenomenon from one side impairs domestic production making it difficult or impossible the increase of consumption of products "made in Albania", and especially affects the growth of imports and trade balance worsening.

Albanian products suffer the lack of a consolidated brand, which would have a demand not only from domestic market but also from the foreign one (It is worthwhile to mention that in countries like Greece and Italy live a considerable number of Albanian emigrants. To conclude, Albania is still suffering the destruction of Albanian industry started in the 90s where under the structural adjustment program advised from IMF Albania would conclude its economic transformation by mass privatizations performing, but this transformation resulted to be more difficult of what was predicted (Stieglitz, 2002). Privatizations in most cases failed due to corruption and less reliable investors (Angjeli, 2007). Often instead of making investments for technology improvement in order to increase production and its quality which from the other side would influence the reduction of imports for that product, the privatizations were bought and used worse than in the period when they were managed by the government. Here we can mention the failure of ARMO privatization as no investment was made and petroleum processing went to zero, the privatization of textile Plant in Berat where in the '90s it hired around 15,000 employees, while after privatization the Plant was sold for scrap, or the wool processing Plant in Shkodra which was sold piece by piece after being privatized to a Montenegrin company which later exported its products in Albania.

\subsubsection{Trade performance over the years}

Albania's trade liberalization in the beginning of 1991 started in conditions when the country's economic structure reflected a general lack almost of all products, even of vital products. The increase of domestic demand as a result of international assistance and remittances (Uruci and Gedeshi, 2003), was reflected in an immediate increase of Albanian economy attendance in international trade although this favored an immediate increase of imports and a significant reduction of exports where as it was mentioned above the Albanian production in that period was almost paralyzed. Albania's foreign trade, after a sinusoidal period of the first post transition decade, began to grow significantly. After 2002, foreign exchange volume almost doubled compared with that of the early ' $90 \mathrm{~s}$. The growth of foreign trade has been faster than that of the production of economy. This resulted in a negative trade balance (table no. 1) and a significant increase of trade openness grade, and in fact this is similar to other transition countries?. If we take into account the ratio between trade volume and GDP, $(X+I M) / G D P$, which indicates the degree of trade openness it is noticed a steady increase over time.

${ }^{7}$ Iapadre. L., Mastronardi. G. (2009 June). L’Albania verso l'Unione europea: il ruolo dell'Italia, a cura di in: Istituto Affari Internazionali, documenti IAI 09, pg.16, 44. 
While the X/GDP ratio is very low: it is the lowest among the Balkans countries ${ }^{8}$. This according to Iapadre and Mastronardi mainly derives from low competitiveness capacity of Albanian enterprises in foreign markets although they are steadily increasing in number, are less prevalent in terms of sectoral and geographical standpoint (Iapadre and Mastronardi, 2009).

Table no.1: Trade balance and the percentage of coverage

\begin{tabular}{|c|c|c|c|c|c|c|c|c|}
\hline Year & Export & Import & $\begin{array}{l}\text { Trade } \\
\text { balance }\end{array}$ & $\begin{array}{l}\text { Trade } \\
\text { volume }\end{array}$ & $\begin{array}{l}\text { The } \% \\
\text { of } \\
\text { coverag } \\
\text { e }\end{array}$ & GDP & $\begin{array}{l}(\mathrm{IM}+\mathrm{X}) / \mathrm{G} \\
\mathrm{DP} \\
\text { In } \%\end{array}$ & $\begin{array}{l}X / G \\
D P \\
\text { in } \%\end{array}$ \\
\hline 1993 & $12,498.9$ & $58,336.4$ & $-45,837.5$ & $70,835.3$ & 21.4 & $266,507.35$ & 26.6 & 0.05 \\
\hline 1994 & $13,387.0$ & $57,018.7$ & $-43,631.7$ & $70,405.7$ & 23.5 & $291,559.04$ & 24.1 & 0.05 \\
\hline 1995 & $18,709.8$ & $66,146.9$ & $-47,437.1$ & $84,856.7$ & 28.3 & $317,507.80$ & 26.7 & 0.06 \\
\hline 1996 & $22,000.9$ & $98,060.0$ & $-76,059.1$ & $120,060.9$ & 22.4 & $346,403.23$ & 34.7 & 0.06 \\
\hline 1997 & $21,044.4$ & $95,021.6$ & $-73,977.2$ & $116,066.0$ & 22.1 & $346,197.79$ & 33.5 & 0.06 \\
\hline 1998 & $31,104.0$ & $126,271.3$ & $-95,167.3$ & $157,375.3$ & 24.6 & $409,208.83$ & 38.5 & 0.08 \\
\hline 1999 & $48,429.6$ & $159,464.8$ & $-111,035.2$ & $207,894.4$ & 30.4 & $471,578.48$ & 44.1 & 0.10 \\
\hline 2000 & $37,037.2$ & $157,109.0$ & $-120,071.8$ & $194,146.2$ & 23.6 & $523,043.38$ & 37.1 & 0.07 \\
\hline 2001 & $44,095.9$ & $190,154.6$ & $-146,058.7$ & $234,250.5$ & 23.2 & $583,368.61$ & 40.2 & 0.08 \\
\hline 2002 & $47,490.5$ & $210,367.7$ & $-162,877.2$ & $257,858.2$ & 22.6 & $622,710.77$ & 41.4 & 0.08 \\
\hline 2003 & $54,486.9$ & $225,982.6$ & $-171,495.7$ & $280,469.4$ & 24.1 & $694,097.16$ & 40.4 & 0.08 \\
\hline 2004 & $62,121.0$ & $236,072.0$ & $-173,951.0$ & $298,193.0$ & 26.3 & $751,021.60$ & 39.7 & 0.08 \\
\hline 2005 & $65,818.0$ & $262,191.0$ & $-196,373.0$ & $328,009.0$ & 25.1 & $814,796.71$ & 40.3 & 0.08 \\
\hline 2006 & $77,405.3$ & $299,147.4$ & $-221,742.1$ & $376,552.7$ & 25.9 & $882,208.79$ & 42.7 & 0.09 \\
\hline 2007 & $97,171.0$ & $376,194.0$ & $-279,023.0$ & $473,365.0$ & 25.8 & $967,670.03$ & 48.9 & 0.10 \\
\hline 2008 & $112,572.0$ & $439,894.0$ & $-327,322.0$ & $552,466.0$ & 25.6 & $\begin{array}{l}1,089,293.1 \\
3\end{array}$ & 50.7 & 0.10 \\
\hline 2009 & $104,514.8$ & $428,838.7$ & $-324,323.8$ & $533,353.5$ & 24.4 & $\begin{array}{l}1,148,082.1 \\
3\end{array}$ & 46.5 & 0.09 \\
\hline 2010 & $161,547.7$ & $477,767.8$ & $-316,220.1$ & $639,315.4$ & 33.8 & $\begin{array}{l}1,222,462.1 \\
2\end{array}$ & 52.3 & 0.13 \\
\hline 2011 & $196,896.6$ & $544,004.0$ & $-347,107.4$ & $740,900.6$ & 36.2 & $\begin{array}{l}1,300,624.0 \\
0\end{array}$ & 57.0 & 0.15 \\
\hline 2012 & $213,023.0$ & $528,478.0$ & $-315,455.0$ & $741,501.0$ & 40.3 & $\begin{array}{l}1,318,833.0 \\
0\end{array}$ & 56.2 & 0.16 \\
\hline $\begin{array}{l}2013 \\
*\end{array}$ & $246,389.0$ & 517,311 & $-270,922$ & $763,700.0$ & 47.6 & $\begin{array}{l}1,324,108.0 \\
0\end{array}$ & 57.7 & 0.19 \\
\hline
\end{tabular}

Source: INSTAT 2014, an our own calculations

\subsubsection{Trade balance and comparative advantages of Albania}

The fact that exports are very important for the economy of a country, finds a wide support from economic literature. In fact, if we calculate GDP by expenditure $\operatorname{method}\{\mathrm{Y}=\mathrm{C}+\mathrm{I}+\mathrm{G}+(\mathrm{X}-\mathrm{M})\}$ we notice that exports have a direct impact on a

8 Coletti. R., Panizza. A. La dimensione economica: L'espansione del modello italiano nei balcani occidentali. Available in http://www.cespi.it/Balcani $\% 20$ PDF/5\%20dimensione $\% 20$ economica.pdf 
country's GDP, but they also have a very important role for financial benefits of a company. So, naturally it is raised the question why Albanian companies have a relatively low level of exports? The reasons are understandable.

In fact when enterprises tend to enter in new markets, face a number of problems such as exchange rates, distances which have a direct impact on the transport cost or different rules of host countries regarding the quality and different product certificates like those of ISO, certificate of origin. All these obstacles can inhibit the export of a country's products. For this reason governmental support in international trade especially for the first years of this process would have a primary role, this support is irreplaceable for emerging businesses (Caffarelli and Veronese, 2013; Czinkota and Zeneli, 2014). Governmental support can be in various forms: the information given for the enterprises, the production orientation, facilitating bureaucratic procedures and support in maintaining the property. If we take a look at table no. 2 where is presented Albania's trade balance of some important products ${ }^{9}$, it is clear that Albania has a negative trade balance in almost every product group. Table no.2: Trade balance of Albania 19932011. (in billion USD)

\begin{tabular}{|c|c|c|c|c|c|c|c|c|c|c|}
\hline Items & 1993 & 1995 & 1997 & 1999 & 2001 & 2003 & 2005 & 2007 & 2009 & 2011 \\
\hline $\begin{array}{l}\text { Meat } \quad \& \\
\text { Diary }\end{array}$ & $(14.59)$ & $(41.02)$ & (23.29) & $(31.03)$ & (21.83) & $(46.91)$ & $(54.32)$ & $(67.33)$ & $(80.49)$ & $(90.38)$ \\
\hline $\begin{array}{l}\text { Vegetables } \\
\text { \& Fruit }\end{array}$ & 0.07 & (20.42) & (17.56) & $(23.88)$ & $(39.77)$ & $(48.88)$ & (65.06) & (74.59) & (78.71) & $(61.32)$ \\
\hline $\begin{array}{l}\text { Cereal \& oil } \\
\text { Prod. }\end{array}$ & (17.35) & (34.78) & $(69.09)$ & (57.13) & $(62.53)$ & $(76.65)$ & (94.17) & (155.12) & $(141.25)$ & $(210.05)$ \\
\hline $\begin{array}{l}\text { Tobacco \& } \\
\text { its subst. }\end{array}$ & 4.39 & $(1.82)$ & 4.86 & (11.98) & $(19.91)$ & $(36.24)$ & $(42.09)$ & (51.48) & (83.38) & (76.66) \\
\hline $\begin{array}{l}\text { Mineral. } \\
\text { fuels, Oil \& } \\
\text { min. waxes }\end{array}$ & $(0.43)$ & $(50.02)$ & $(16.54)$ & $(36.74)$ & (130.01) & $(154.00)$ & (204.88) & (530.08) & (409.04) & (537.66) \\
\hline Leathers & (1.86) & $(2.85)$ & (6.20) & (14.01) & (16.65) & (44.28) & $(43.27)$ & (64.68) & $(57.36)$ & (68.18) \\
\hline $\begin{array}{l}\text { Wood \& its } \\
\text { articles }\end{array}$ & (3.06) & $(10.11)$ & $(14.02)$ & $(26.98)$ & $(37.25)$ & $(63.52)$ & (99.05) & $(171.79)$ & $(199.03)$ & $(209.55)$ \\
\hline $\begin{array}{l}\text { Clothing \& } \\
\text { textiles prod. }\end{array}$ & 2.71 & $(0.67)$ & $(14.82)$ & 52.51 & 52.01 & 68.39 & 129.39 & 176.47 & 160.95 & 231.08 \\
\hline Metals & 5.37 & 17.56 & $(23.54)$ & $(48.35)$ & $(83.87)$ & (109.78) & $(166.13)$ & $(319.70)$ & $(387.48)$ & $(242.00)$ \\
\hline $\begin{array}{l}\text { Machinery \& } \\
\text { Vehicles }\end{array}$ & 175.00 & 122.19 & (127.62) & (159.23) & $(312.29)$ & (394.62) & $(594.99)$ & $(848.49)$ & $\begin{array}{l}(1,016.0 \\
2)\end{array}$ & $\begin{array}{l}(1,029.3 \\
4)\end{array}$ \\
\hline Amount & $(222.10)$ & $(313.87)$ & $(307.80)$ & $(356.82)$ & $(672.12)$ & $(906.50)$ & $\begin{array}{l}(1,234.5 \\
7)\end{array}$ & $\begin{array}{l}(2,106.8 \\
0)\end{array}$ & $\begin{array}{l}(2,291.8 \\
1)\end{array}$ & $\begin{array}{l}(2,294.0 \\
6)\end{array}$ \\
\hline Other & $(72.56)$ & (132.95) & (173.28) & (259.84) & (348.13) & (503.46) & $(687.96)$ & $\begin{array}{l}(1,005.0 \\
3)\end{array}$ & $\begin{array}{l}(1,195.7 \\
9)\end{array}$ & $\begin{array}{l}(1,186.3 \\
4)\end{array}$ \\
\hline Total & (294.67) & $(446.82)$ & $(481.08)$ & (616.66) & $\begin{array}{l}(1,020.2 \\
5) \\
\end{array}$ & $\begin{array}{l}(1,409.9 \\
6) \\
\end{array}$ & $\begin{array}{l}(1,922.5 \\
4) \\
\end{array}$ & $\begin{array}{l}(3,111.8 \\
2)\end{array}$ & $\begin{array}{l}(3,487.6 \\
0) \\
\end{array}$ & $\begin{array}{l}(3,480.4 \\
0) \\
\end{array}$ \\
\hline
\end{tabular}

Source: Bank of Albania 2014, and our own work.

Also referring to INSTAT data it can be noted that Albanian exports are concentrated in a very limited number of economic sectors mainly composed of raw materials (minerals), crude oil, decorative stones, construction sector materials etc.

9 The classification in 10 product groups in table 2 is a result of around 98 individual products grouping, reduced according their similarity in only 10 groups. The rest is grouped at "Others". 
The only category that has a clear comparative advantage and a positive trade balance is the category clothing and textile products, i.e. fasson sector. As it was mentioned before Albania has a positive balance in quantity of crude oil, minerals, decorative stones etc., but if we consider the monetary value of these products, (category: mineral fuels, oils, mineral waxes) this surplus disappears. To make this phenomenon clearer let's give an example: in 2013 Albania has exported about 1 million tons of crude oil and in the same year has imported about 400 thousand tons of processed oil ${ }^{10}$. While domestic consumption was about 550 thousand tons (400 thousand tons from import and 150 thousand tons from domestic production). Referring to table 2, the export monetary value of this category is very low compared to the import value and in this way the trade balance is negative. It seems that Albania does not rank in a favorable position among other countries of the world or even regional countries, regarding the figures or international trade indexes. We can mention here the Grubel-Lloyd index (GL Index) which is an indicator of a country's intra-industry trade. The values of this index for Albania vary between $0.14-0.1711$, and are very low compared to other industrialized countries, or developed countries. Another explanatory of trade specialization model is Revealed Comparative Advantage (RCA), or the so-called Balassa Index, which measures the degree of a country's trade specialization in a specific industry (product) ${ }^{12}$.

$\mathrm{RCA} i j=(\mathrm{X} i j / \mathrm{X} w) /(\mathrm{X} i / \mathrm{X} w)$

Where $\mathrm{X} i j$ are exports of country $i$ in industry $j$, X $w j$ represents world exports of industry $j, \mathrm{X} i$ are total exports of country $i$, and $\mathrm{X} w$ represent total world exports.

Based on this index, a country is specialized in exports of a certain product if the market share it takes in this product is higher than average or, equivalently, if the product shares in the exports of country $i$, is higher than the share of exports in the reference area (world, region, union of countries). A country reveals comparative advantage in products with an index higher than 1. Regarding our country, it would be meaningless to calculate this index between Albania and the rest of the world, because this index will appear result equal to zero in all products, due to the negligible share that our country has in international trade. If the reference area is no longer considered the world, but it narrows in EU, it still results that Albania does not reveal any comparative advantage in any of industries / products, despite the fact that two of its main trading partners are EU countries (Italy and Greece). This is due to the low share of Albanian export in a certain product against this region, in the total EU exports in this specific product. RCA index results almost zero even in textile sector, the only sector where our country have a positive trade balance. If we see the Albanian trade with other regional countries, this would not be representative because our country has no significant trade transactions with countries of the region, compared to Italy or Greece.

To conclude it can be said that our country is relatively rich in natural resources and has a relatively very low cost of labor force. This has affected that as basic export products to serve the underground products and labor intensive products which are ordered from developed countries to utilize the low cost of labor force.

10 METE Report

11 World Trade Report, 2013: "Factors Shaping the Future of World Trade", pg 70.

12 Balassa, B. (1965). Trade liberalisation and revealed comparative advantage. Manchester School of Economics and Social Studies, 33(2), 99-123. 


\section{The Trend of Consumption and its Identification According Product's Origin}

The last twenty years consumption has recorded radical transformation, thanks to the economic situation of the country and especially thanks to the change of lifestyle and the population's needs. The increase of social welfare and employment after 1992 has favored a significant increase in consumption expenses in Albania; from 464 dollars per capita in 1990 , to $3484 \$$ / capita in 2008. In 2009, the crisis that struck the Albanian economy led to a significant decrease of GDP decreasing from $7.5 \%$ in 2008 to $0.7 \%$ in $2013^{13}$. The same trend has had the dynamic of consumption which clearly shows the difficult phase of Albanian families, taking in consideration that per capita consumption fell by $\$ 3,484$ (2008) to $\$ 3,047$ (2009), and finally to about $\$ 2,973(2012)^{14}$.

This evolution of per capita consumption shows the most difficult moment after that of 1997, where per capita consumption fell significantly from $\$ 958$ in 1996 to $\$ 690$. According to De Novellis, consumption reflects the weakness of disposable income. According him the complex consumption dynamic is in line with the income level ${ }^{15}$. In fact, in this period it is noticed an increase of unemployment which was accompanied at the same time with a decrease of remittances from 719 million Euros in 2007, to 497 million Euros ${ }^{16}$. It is also noticed a general decline of consumption expenditures/GDP ratio, shifting from $84.6 \%$ in 2008 to $78.3 \%$ in 2012. Now everyone consumes less, consumers are more careful in what they purchase, evaluate more the products and services, avoid unnecessary expenditures, so it is noticed a restrictive psychological effect, in the sense that individuals are increasingly saving.

\subsection{Consumption Identification according product's origin.}

As can be clearly seen from table 1, Albania has a negative trade balance. It mainly exports raw materials and products of the tertiary sector produced in Albania because of low cost of labor force and imports a wide range of products ranging from agriculture ones, livestock, grocery and technologic products. So, Albania is a country that most of the daily consumption products are provided from imports. If we analyze the geographical distribution of imports, based on the Bank of Albania statistics ${ }^{17}$, it is noted that since from the beginning of the ' 90 s Italy has been our main trade partner, regarding both imports and exports. Exports from 43\% in 1993 reached to $75 \%$ in 2003, to decrease again in 2012 in about 51\%. An interesting is data that about $90 \%$ of Albanian exports go for European countries. Regarding imports, it is seen an overhaul of the imported quota with Italy, although it remains an important partner, from which Albania imports semi-processed products, food products, machinery, technology, etc. While Albania imports from Germany machinery, electronics and from neighboring countries like Macedonia and Kosovo our country imports, mainly agricultural products. Albania's second trade partner is Greece although there has been recently a change of import quotas from $29 \%$ in 2001 to $10 \%$ in 2012. However it can be affirmed that

\footnotetext{
13 Bank of Albania, Macroeconomic statistics, 2014.

14 Ivan Kushnir's Research Center, 2014

15 De Novellis. F. La lunga crisi dei consume delle famiglie italiane, Consumatori diritti e mercato. No.03/2008 pg. 129-141.

16 Bank of Albania, Macroeconomic statistics, 2014.

17 Bank of Albania, statistics, foreign trade, Imports/ Exports by country, 2014.
} 
Greece remains a very important partner for our imports, this also thanks to geographical proximity, especially the southeastern part of Albania.

\section{Conclusions}

Albania since from the beginning of 1992 has experienced a great openness of economy in international trade. The liberalization of economy and prices along with public enterprises privatization paradoxically caused a paralysis of country's production transforming the Albanian economy into a fully dependent economy from other countries.

Remittances and domestic and foreign investment increment has positively affected the reduction of this dependence although it is obvious there is still lots of work to do. Concerning its economic specialization it is noted that our country is relatively rich in natural resources and has a relatively low cost of labor force but if we analyze the indicators of comparative advantages, the Balassa index or GL index, it is clear that Albania does not reveal pure comparative advantages. Considering the above facts, the composition of basic export products are exactly the underground products and laborintensive products which are ordered from developed countries to exploit the low cost of labor force. It is clear that a necessary condition for revitalizing the economy and a continuous improvement of trade balance, is state intervention in production orientation, facilitating bureaucratic procedures and help in maintaining ownership and above all: investment orientation in order to increase productivity, reduce imports and increase exports. The so far exports performance is disappointing. They are mainly concentrated in unprocessed raw materials and fasson products and have a low impact on country's economy and especially do not produce for the domestic market. To overcome this economic cramps an immediate intervention in concessions should occur, in order to favor those that invest in products processing and technology increase. In this way the productivity, employment and production for the domestic market, would increase. In is also an emergency the increase of local business competitiveness as well as product and local brands consolidation. An option could be the encouragement of foreign investment in those economic sectors with deficit trade balance.

\section{Bibliography}

Aida, G., Eva, Dh. (2012 December). The Problems of the Albanian Agro-Industry through Analysis of Exports - Imports and Competitive Environment (Region of Korca).Journal of Knowledge Management, Economics \& Information Technology. Vol. 2 Issue 6, pg. 111-123.

ACIT Trade Report 2013, pg 31.

Bank of Albania, Macroeconomic statistics, 2014

Caffarelli, V., Veronese, G. (2013 September). Il sistema paese a supporto dell' internazionalizzażione, Banca d'Italia, Questioni di Economia e Finanza, No, 196.

Coletti. R., Panizza. A. La dimensione economica: L'espansione del modello italiano nei balcani occidentali.

Czinkota, M., Zeneli, V. (2014 January) International Marketing: An Imperative for Southeast Europe: the 10th edition of the Marshall Center's "Security Insights" series.

De Novellis. F. La lunga crisi dei consume delle famiglie italiane, Consumatori diritti e mercato. No.03/2008. Pg. 129-141.

Frankel, J., (2000): “Globalization of the Economy". National Bureau of Economic Research: Working Paper no. 7858. Pg: 21, 35. 
Garofoli, G., Angeli F. (2014). Economia e politica economica in Italia. Lo sviluppo economico italiano dal 1945 ad oggi, Milano

Iapadre. L., Mastronardi. G. (2009 June). L'Albania verso l'Unione europea: il ruolo dell'Italia, a cura di in: Istituto Affari Internazionali, documenti IAI 09, pg.16, 44.

Ivan Kushnir's Research Center, 2014

METE Report 2013

Ricardo, D. (1817): "Principles of political economy and taxation"

Rodrik, D., (1997): "Globalization, Social Conflict and Economic Growth, Harvard University". Pg. 11

Sowell. Th. (2011):'Basic Economics. A Common Sense Guide to the Economy", Fourth Edition

Skreli, E., Tanku, A. (2002). The process of Trade Policies. The Regulation of the Presence and Interaction of Institutions. Available at www. pdc.ceu.hu

Torrens, Th.: (1815):" An Essay on the external corn trade"

Vangjeli, E., Stillo, S., Teneqexhi, M.(2010). Stimulation and Good management of food production: a most important indicator for a constant regional development.

World Trade Report, 2013: "Factors Shaping the Future of World Trade", pg 70.

Xhepa, S., Agolli, M.: “Albania’s Foreign Trade through a Gravity Approach”, Pg 15. 